Article

\title{
A Scientometric Overview of Global Dinoflagellate Research
}

\author{
Carlos Yure B. Oliveira ${ }^{1, *(\mathbb{D}}$, Cicero Diogo L. Oliveira ${ }^{2}\left(\mathbb{D}\right.$, Marius N. Müller ${ }^{3}{ }^{(\mathbb{C}}$, \\ Elizabeth P. Santos ${ }^{1}$ D, Danielli M. M. Dantas ${ }^{1}$ and Alfredo O. Gálvez ${ }^{1}$ \\ 1 Departamento de Pesca e Aquicultura, Universidade Federal Rural de Pernambuco, Recife 52171-900, Brazil; \\ santos.e.p.26@gmail.com (E.P.S.); danielli.dantas@ufrpe.br (D.M.M.D.); alfredo.galvez@ufrpe.br (A.O.G.) \\ 2 Instituto de Ciências Biológicas e da Saúde, Universidade Federal de Alagoas, Maceió 57072-900, Brazil; \\ linsdiogoc@gmail.com \\ 3 Departamento de Oceanografia, Universidade Federal de Pernambuco, Recife 50740-550, Brazil; \\ mariusnmuller@gmail.com \\ * Correspondence: yureboliveira@gmail.com
}

Received: 16 October 2020; Accepted: 23 November 2020; Published: 25 November 2020

check for updates

\begin{abstract}
Understanding the evolution of scientific literature is a critical and necessary step for the development and strengthening of a research field. However, an overview of global dinoflagellate research remains unavailable. Herein, global dinoflagellate research output was analyzed based on a scientometric approach using the Scopus data archive. The basic characteristics and worldwide interactions of dinoflagellate research output were analyzed to determine the temporal evolution and new emerging trends. The results confirm that dinoflagellate research output, reflected in the number of publications, is a fast-growing area since the mid-1990s. In total, five research subareas emerged using a bibliometric keywords analysis: (1) "symbiosis with coral reefs", (2) "phylogeny", (3) "palynology", (4) "harmful algal blooms" and (5) "nutrition strategies". Dinoflagellate publications were modeled by fish production (both aquaculture and fisheries) and economic and social indexes. Finally, directions for future research are proposed and discussed. The presented scientometric analysis confirms that dinoflagellate research is an active and important area with focus on mitigating economic impacts, especially in regard to fish production.
\end{abstract}

Keywords: bibliometric analysis; Dinophyceae; publications; microalgae; Scopus

\section{Introduction}

Dinoflagellates are protists characterized by two flagella and the pigment peridinin in combination with chlorophyll a, b or c. A large fraction of these microorganisms is mixotrophic, combining photosynthesis with phagotrophy and/or myzocytosis facilitating bloom formation when nutrients are scarce in the euphotic zone of coastal waters [1]. This functional group of microalgae has a primary marine occurrence but is also commonly found in freshwater and estuarine environments. Dinoflagellates are a highly diverse and abundant group of microalgae species and in terms of cell size substantially smaller than diatoms [2].

Claims by botanists, zoologists and micropaleontologists, regarding the taxonomic classification of dinoflagellates, were recurrent until the use of molecular tools which improved the evolutionary understanding and the complex life cycles of dinoflagellates. In fact, the literature on dinoflagellates, especially those published in the last century, is widely diffused, complex and partly contradictory. Nonetheless, dinoflagellates have been recognized for their essential role in the functioning of aquatic ecosystems, especially with regard to: primary productivity [3], symbiosis with reef-building corals [4], harmful algal blooms (HABs) [5] and toxin production and associated cascading trophic effects [6]. 
Dinoflagellates have been studied in regard to their production of highly diverse secondary metabolites. These compounds are, in general, not vital for the cell's survival and reproduction, and include a variety of hormones and allelochemicals. The toxins are a group of allelochemicals that can have harmful effects on higher organisms, such as fish, birds and mammals [7]. Historical records of toxins produced by dinoflagellates include (1) the Captain George Vancouver's crew poisoning after eating contaminated shellfish in 1793 [8], (2) human poisoning caused by the consumption of mussels in 1927 (California, United States), which has been related to the presence of Alexandrium catenella [9], and (3) the first proven cases of paralytic shellfish poisoning (PSP) in humans were recorded in 1976 [10]. Before 1970, toxic dinoflagellate blooms were recorded in Europe, North America and Japan and as of 1990, toxic species were observed in the Southern Hemisphere in conjunction with a general global increase in the distribution of toxins due to transportation of many HAB species via ship ballast waters $[8,11]$. Since then, HABs have caused serious public health problems and negatively impacted fishing and aquaculture industries, including the recent Godzilla Red Tide event in Chile- the largest recorded fish farm mortalities [11-14]. Additionally, dinoflagellates may cause problems in freshwater environments. Particularly Ceratium spp. have been reported in several freshwater environments in South America since the mid-2000s, and, although it is not a toxic genus, the postbloom accumulation of Ceratium spp. biomass may cause low oxygen environments due to an increased bacterial activity impacting survival rates of fish and crustacean species $[15,16]$.

Bibliometric or scientometric analyses have become fundamental tools for analyzing current trends within the scientific literature and provide guidelines and motivations for future research in specific fields or areas. Recently, bibliometric analyses have been reported on eutrophication [17], diatom research [18], microcystins in China [19], photosynthesis [20] and microalgae research [21]. However, although these reports indirectly addressed dinoflagellate research, curiously this area has not been specifically emphasized — with the exception of Barbosa Noga and Ferreira Gomes [22] summarizing Brazilian dinoflagellate studies.

Exclusively quantitative bibliometric research is not necessarily the best approach to assess and discuss global scientific productivity [23], however, when combined with qualitative data, it can generate valuable indices for recognizing current status and future prospects within a given research field/area. Herein, dinoflagellate research was quantitatively and qualitatively analyzed to provide an improved understanding of the global research situation and emerging trends. The basic characteristics, development of publications, worldwide distribution, mainstream journals, keywords and genera of dinoflagellates research were analyzed in detail. Diverging research trends and subareas were identified to raise awareness on possible gaps in scientific cooperation.

\section{Methods}

\subsection{Data Collection}

The information of scientific publications was based on the Elsevier Scopus database (obtained on 31 January 2020). A detailed search was carried out using [TITLE-ABS-KEY (dinoflagellate)] as search query. This search resulted in 17,871 publications after limiting the search timescale from 1970 to 2019 . Although the term "dinoflagellates" has presented the same number of publications as "dinoflagellate", it should be noted that if a different term is used, such as "Dinophyceae" (10,475 publications), variations may occur. The obtained results were processed by author keywords with identical meanings and by discarding keywords not related to phycology such as "article", "priority journal" and "non-human". Particularly the term "non-human" appears in the sixth place (2995 publications) among the most frequent keywords, however, when analyzing in detail the publications [TITLE-ABS-KEY (dinoflagellate) AND LIMIT-TO (EXACTKEYWORD, “Nonhuman")], the results did not contain any publications with the term "non-human" and, conclusively, this keyword was discarded. 


\subsection{Bibliometric Analysis}

The publications obtained were organized and processed using the OpenRefine software. This software tool allows for the eliminating of duplicate records or grouping of different representations of the same reality [21,24].

The characteristics of bibliometric analyzed literature include both qualitative information and quantitative data. Herein, the elements investigated were: the document type and the language, the number of publications per year, the distribution of publications by research institutions and country, the keywords, the sources and research networks. In the case of research networks, a community can be defined as a set of nodes that are more densely connected with each other than with the rest of the network. Community detection was carried out using the VOSviewer software (version 1.6.14). This software enables the creation of charts categorized by countries or keywords what is represented by a node. The connections between two nodes represent the collaboration between the two keywords (or countries) in a research file.

\subsection{Mapping and Modeling Scientific Production}

Population and territorial extension data were obtained from the Worldometer website (http://www.worldometers.info/world-population/population-by-country/) and were used for normalization of scientific production per inhabitants and per territorial extension. A world map was colored according to number of publications of each country to compare the spatial distribution of published dinoflagellate publications.

In order to verify the influence of economic, environmental and social data on scientific production of dinoflagellates, we fitted generalized linear model (GLM), with a Gaussian error distribution and an identity link function for continuous data. The GLM was made using the 'Imer' function from the package 'Ime4' [25]. Gross Domestic Product (GDP) and Human Development Index (HDI) were downloaded from The World Bank Database (https://data.worldbank.org/). Environmental Sustainability Index (ESI) was downloaded from the Yale University (https://epi. yale.edu/). This index summarizes 32 performance indicators and 11 pollutant emission categories in a single score for environmental health and ecosystem vitality. Additionally, agricultural production data were evaluated according to the global fish production by aquaculture (Aqua) and by capture (Capt) and to the fertilizer consumption (Fert) downloaded from the Fisheries Division of the Food and Agriculture Organization of the United Nations (http://www.fao.org/fishery/topic/16140) and from The World Bank Database, respectively. Data were extracted from 1970 to 2019 (depending of data availability) to calculate the according averages to be used in the model.

All analyses were performed in the RStudio software v 1.2.5 (Boston, MA, USA).

\section{Results}

\subsection{Basic Characteristics of the Dinoflagellate Literature}

The 17,871 publications, resulting from the initial search performed on the Elsevier Scopus platform, were composed of 16,258 articles (91\%), 619 reviews (3.46\%), 480 conference papers (2.68\%), 214 book papers $(1.19 \%)$ and 300 others (1.67\%). Publications were published in English $(17,071 \cong 95.52 \%)$, Chinese $(205 \cong 1.15 \%)$, Spanish and French $(174 \cong 0.97 \%)$, Japanese $(116 \cong 0.65 \%)$ and other languages $(211 \cong 1.18 \%)$.

\subsection{Temporal Development of Publications}

The annual numbers of publications between 1970 and 2019 are presented in Figure 1. In 1970, 30 documents on dinoflagellates were published, and until the early 1980s a low oscillation in the number of publications could be observed (ranging from 26 to 90). From the quantitative perspective, a crucial moment for dinoflagellates research was registered in 1991 with a remarkable increase in the number of publications. In addition, in 2003 the number of publications exceeded 500 for the 
first time. In mid-2014 the number of publications diverged from the fitted exponential trend. As a result, in 2017, only 862 publications were achieved, a lower number than projected (1000 publications). Furthermore, dinoflagellate publications of the last decade corresponded to $43.96 \%$ (7856 publications) of all publications since 1970. Among these publications, articles (92.11\%) and the English language (95.69\%) presented similar percentages when compared to the last 50 years. A linear regression model was fitted to the data of the last decade and is showed in Figure S1. Although the linear model of the last decade $\left(R^{2}=0.75\right)$ was less expressive than the exponential one presented in Figure $1\left(R^{2}=0.96\right)$, it projected that in 2025, 1000 publications on dinoflagellates would be achieved (8 years later when compared to the exponential model).

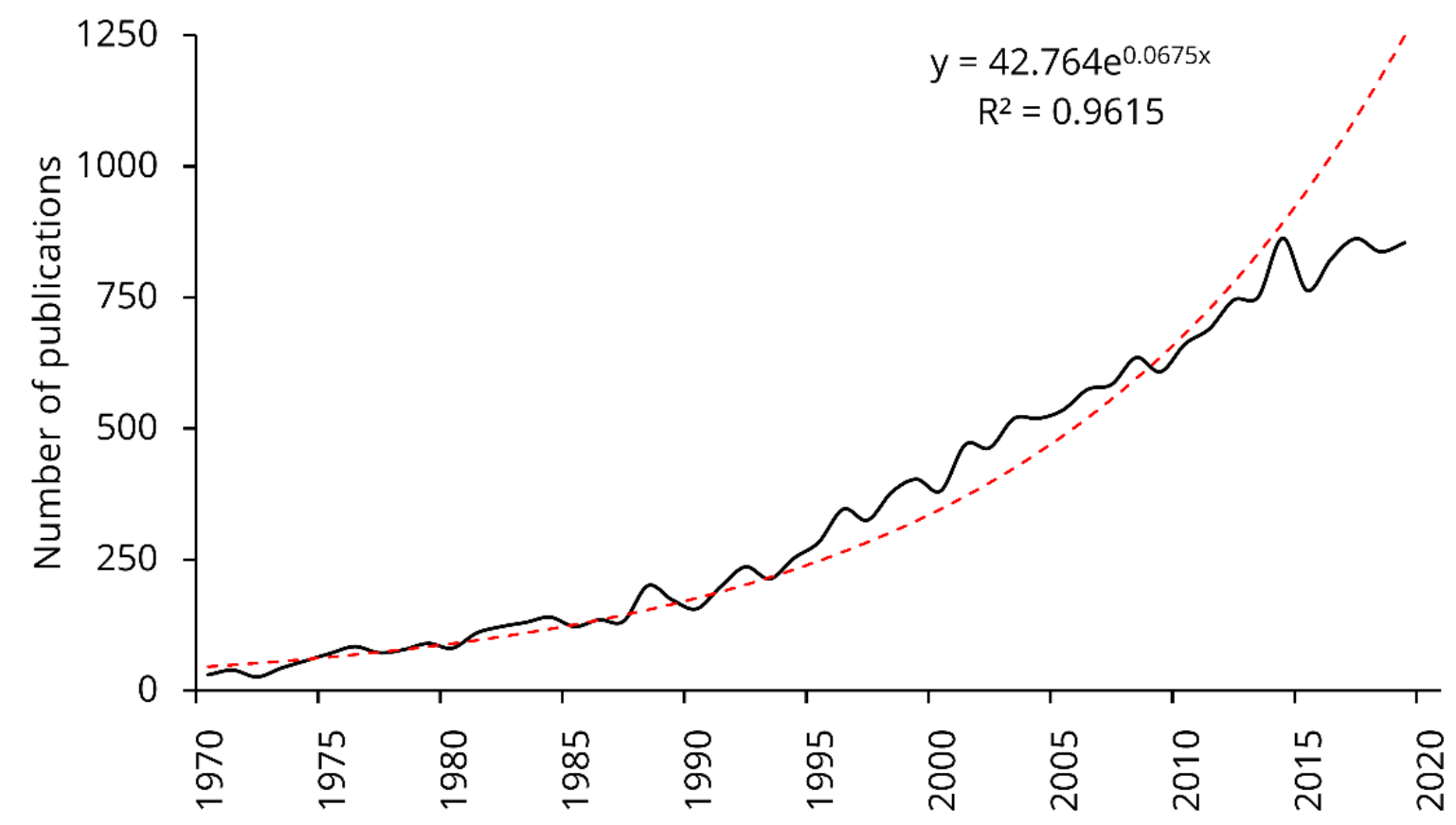

Figure 1. Trend in the number of publications from 1970 to 2019.

\subsection{Global Distribution of Publications}

A world map of the scientific production (Figure 2) indicates research on dinoflagellates has been conducted on all continents. The countries that published the most publications were the United States, Japan and the United Kingdom. In general, specific European countries published more publications than countries of America, Asia, Oceania and Africa. This ranking order changed when the scientific production was normalized to the population data and resulted in a new ranking with New Zealand, Norway and Australia in the top three positions. China and India, with populations of over one billion people, occupied the last positions in this normalized ranking. Using the normalization per land area data, Netherlands, the United Kingdom and Denmark were in the top three positions. Only the United Kingdom appeared multiple times in the top three positions of all applied rankings (Table 1). In relation to the countries that presented the most publications on dinoflagellates over the last decade, the United States remained at the same position, followed by China, Germany and France. The most dominant continent in terms of the number of publications was Europe with Germany, France, the United Kingdom and Spain among the top 10 countries (Table S1).

The top 20 research centers are listed in Table 2 and headed by: Center National de la Recherche Scientifique (CNRS), Alfred-Wegener-Institute and the Chinese Academy of Sciences. Although the United States leaded the ranking of publications by countries, only one North American institution (Woods Hole Oceanographic Institution) did appear in the top 20 institutions. This ranking was led by European and Asian institutions (three French, two German, two Spanish, one Dutch, one Danish, three Japanese, three Chinese and one Russian). 


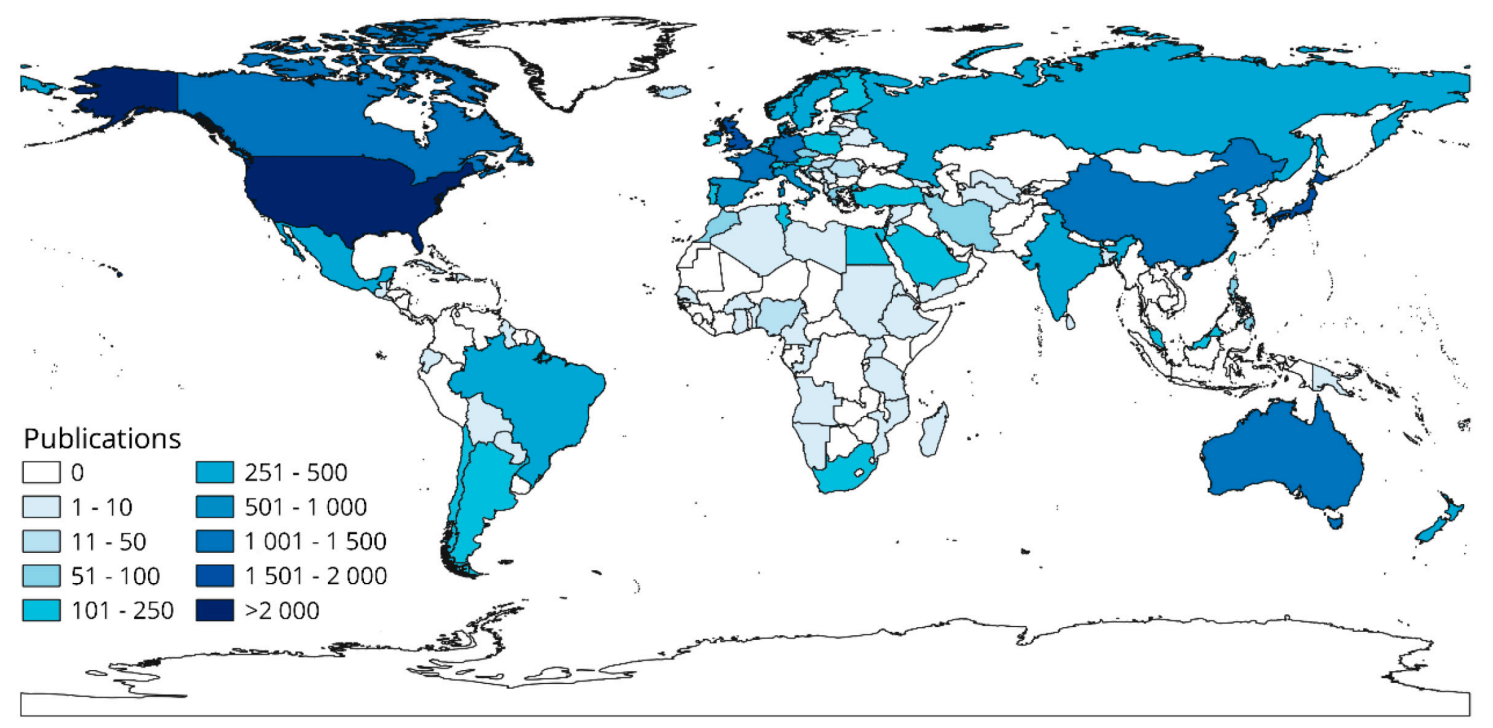

Figure 2. World map according to the number of documents.

Table 1. Publications (n) distribution by countries.

\begin{tabular}{|c|c|c|c|c|c|}
\hline Country & M Habitants & Dimension $\left(\mathrm{M} \mathrm{km}^{2}\right)$ & $n$ & n/M Habitants & $n / 10^{3} \mathrm{~km}^{2}$ \\
\hline United States & 331.00 & $9,147,420$ & 4992 & 15.08 & 0.638 \\
\hline Japan & 126.48 & 364,555 & 1590 & 12.57 & 4.265 \\
\hline United Kingdom & 67.89 & 241,930 & 1541 & 22.70 & 6.354 \\
\hline Germany & 83.78 & 348,560 & 1470 & 17.54 & 4.121 \\
\hline France & 65.27 & 547,557 & 1393 & 21.34 & 2.526 \\
\hline China & 1439.32 & $9,388,211$ & 1256 & 0.87 & 0.131 \\
\hline Canada & 37.74 & $9,093,510$ & 1225 & 32.46 & 0.123 \\
\hline Australia & 25.50 & $7,682,300$ & 1110 & 43.53 & 0.144 \\
\hline Spain & 46.75 & 498,800 & 958 & 20.49 & 1.898 \\
\hline Italy & 60.46 & 294,140 & 619 & 10.24 & 2.054 \\
\hline South Korea & 51.27 & 97,230 & 564 & 11.00 & 5.696 \\
\hline Denmark & 5.79 & 42,430 & 260 & 44.89 & 6.036 \\
\hline New Zealand & 4.82 & 263,310 & 437 & 90.62 & 1.615 \\
\hline Netherlands & 17.13 & 33,720 & 423 & 24.69 & 10.186 \\
\hline Norway & 5.42 & 365,268 & 419 & 77.29 & 1.088 \\
\hline Sweden & 10.10 & 410,340 & 399 & 39.51 & 0.886 \\
\hline India & 1380.00 & $2,973,190$ & 352 & 0.25 & 0.107 \\
\hline Russian Federation & 145.93 & $16,376,870$ & 336 & 2.30 & 0.002 \\
\hline Mexico & 128.93 & $1,943,950$ & 336 & 2.61 & 0.171 \\
\hline
\end{tabular}

Figure 3 shows the affinity of the collaboration of countries with $>250$ publications on dinoflagellates. The 20 countries, plotted in this analysis, were distributed across four communities: the first formed by Asian countries, the United States and Canada; the second formed by European countries, Brazil and Mexico; the third formed by European countries, India and the Russian Federation; and the fourth formed by Australia and New Zealand. The United States and the United Kingdom demonstrated connections with all four communities. More frequent connections (represented by the thickness of the line) could be observed between the United States and Australia, and the United Kingdom and Germany. 
Table 2. Top 20 research centers.

\begin{tabular}{lcc}
\hline \multicolumn{1}{c}{ Affiliation } & Country & $n$ \\
\hline CNRS Centre National de la Recherche Scientifique & France & 494 \\
Alfred-Wegener-Institut Helmholtz-Zentrum für Polar-und & Germany & 423 \\
Chinese Academy of Sciences & China & 378 \\
Woods Hole Oceanographic Institution & United States & 338 \\
IFREMER Institut Francais de Recherche pour I'Exploitation de la Mer & France & 331 \\
Sorbonne Universite & France & 286 \\
Københavns Universitet & Denmark & 285 \\
Hokkaido University & Japan & 250 \\
University of Bremen & Germany & 238 \\
CSIC-Instituto de Ciencias del Mar ICM & Spain & 233 \\
The University of British Columbia & Canada & 222 \\
University of Tokyo & Japan & 203 \\
Scripps Institution of Oceanography & Canada & 201 \\
Instituto Espanol de Oceanografia & Spain & 202 \\
Utrecht University & Netherlands & 197 \\
Ministry of Education China & China & 194 \\
Russian Academy of Sciences & Russian Federation & 193 \\
University of Queensland & Australia & 194 \\
Tohoku University & Japan & 193 \\
Ocean University of China & China & 188 \\
\hline
\end{tabular}

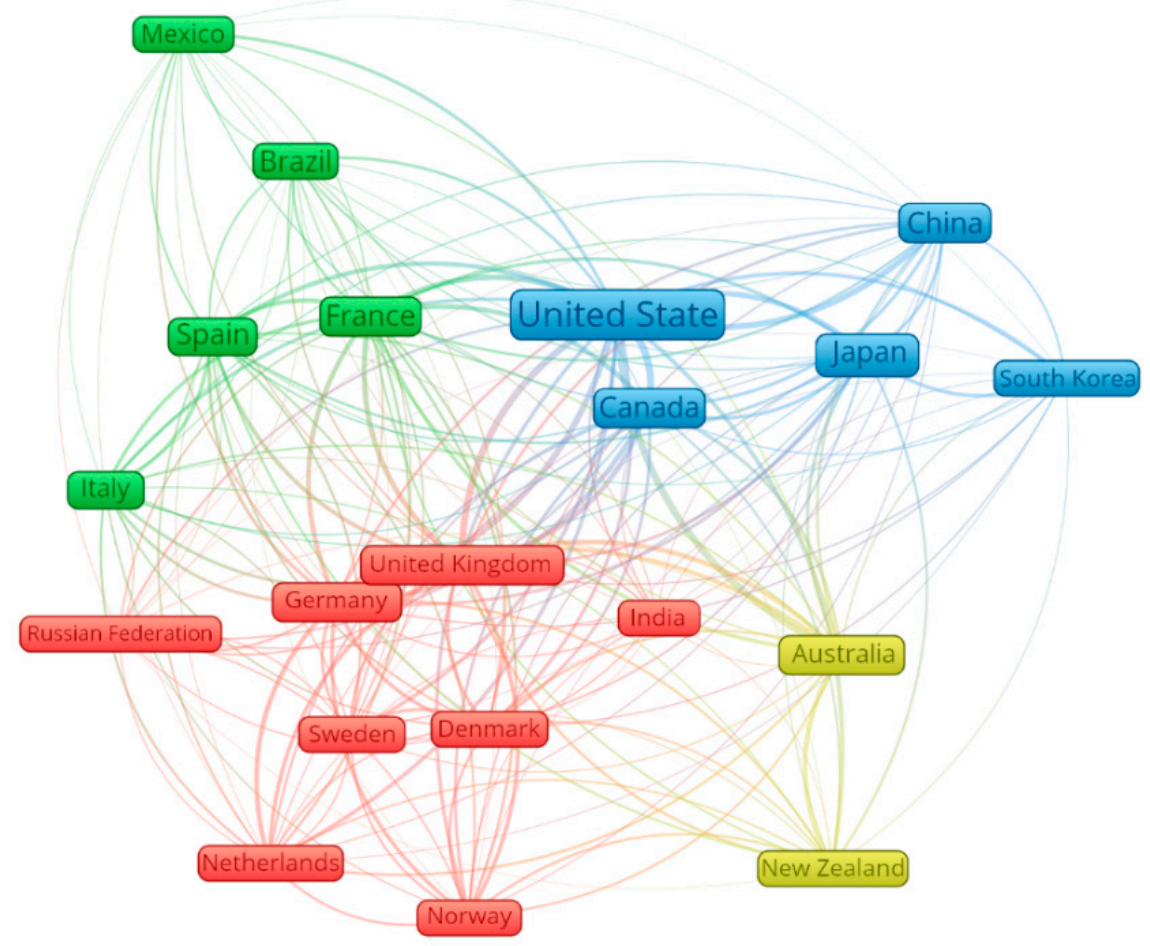

Figure 3. Visualization map of countries communities regarding dinoflagellate research.

\subsection{Sources and Citations}

The total number of publications, the JCR Impact Factor and the SJR CiteScore of the top 20 journals are listed in Table 3. The highest number of publications on dinoflagellates was found in the journal Harmful Algae, which was associated with the highest CiteScore index. On the other hand, Marine Pollution Bulletin had the highest Impact Factor of this ranking. Among the high impact phycology journals (IF $\geq 2$ ), Algal Research (IF = 4.008), Journal of Applied Phycology (IF = 3.016), European Journal of Phycology (IF = 2.756) and Algae $(\mathrm{IF}=2.914)$ did not appear in this ranking. 
In addition, PLOS ONE was the only multidisciplinary journal listed in this ranking. In the last decade of publications, Harmful Algae continued to lead the number of publications. Furthermore, the journal Marine Drugs (IF = 4.073), which did not appear in the previous ranking, emerged on the ninth position in relation to the number of publications and it achieved the highest impact factor index (Table S2).

Table 3. Top 20 journals with published dinoflagellate research with the associated Impact Factor, CiteScore and number of documents $(n)$.

\begin{tabular}{lccc}
\hline \multicolumn{1}{c}{ Journal } & Impact Factor (2019) & CiteScore (2019) & $\boldsymbol{n}$ \\
\hline Harmful Algae & 3.707 & 8.8 & 749 \\
Journal of Phycology & 2.328 & 4.6 & 614 \\
Marine Ecology Progress Series & 2.326 & 4.2 & 509 \\
Journal of Plankton Research & 2.146 & 3.9 & 401 \\
Marine Biology & 2.050 & 4.3 & 322 \\
Review of Palaeobotany and Palynology & 1.425 & 3.1 & 251 \\
Toxicon & 2.201 & 4.1 & 259 \\
PLoS ONE & 2.740 & 5.2 & 257 \\
Journal of Environmental Marine Biology and Ecology & 2.247 & 4.6 & 237 \\
Limnology and Oceanography & 3.778 & 7.5 & 234 \\
Palynology & 1.330 & 2.0 & 236 \\
Hydrobiologia & 2.385 & 4.7 & 195 \\
Aquatic Microbial Ecology & 1.841 & 3.2 & 195 \\
Phycologia & 2.276 & 3.7 & 188 \\
Estuarine Coastal and Shelf Science & 2.333 & 4.5 & 186 \\
Marine Pollution Bulletin & 4.049 & 6.7 & 181 \\
Palaeogeography Palaeoclimatology Palaeoecology & 2.833 & 5.1 & 181 \\
Deep Sea Research. Part II Tropical Studies in Oceanography & 2.697 & 6.6 & 167 \\
Journal of Eukaryotic Microbiology & 2.143 & 4.6 & 148 \\
Marine Micropaleontology & 2.207 & 3.7 & 145 \\
\hline
\end{tabular}

The top 20 most cited publications and their main information are listed in Table 4. This ranking was headed by the journal Limnology and Oceanography, with four publications, followed by Nature and Science, with three and two publications, respectively. The publication with the highest total number of citations "Hoegh-Guldberg et al., 2007" received also the highest number of citations per year. Although Harmful Algae was the journal with the highest number of published publications, it did not appear in this specific list. Exclusively, the journals Limnology and Oceanography, Phycologia and Journal of Phycology appeared in both rankings.

Table 4. Top 20 mostly cited publications on dinoflagellate research.

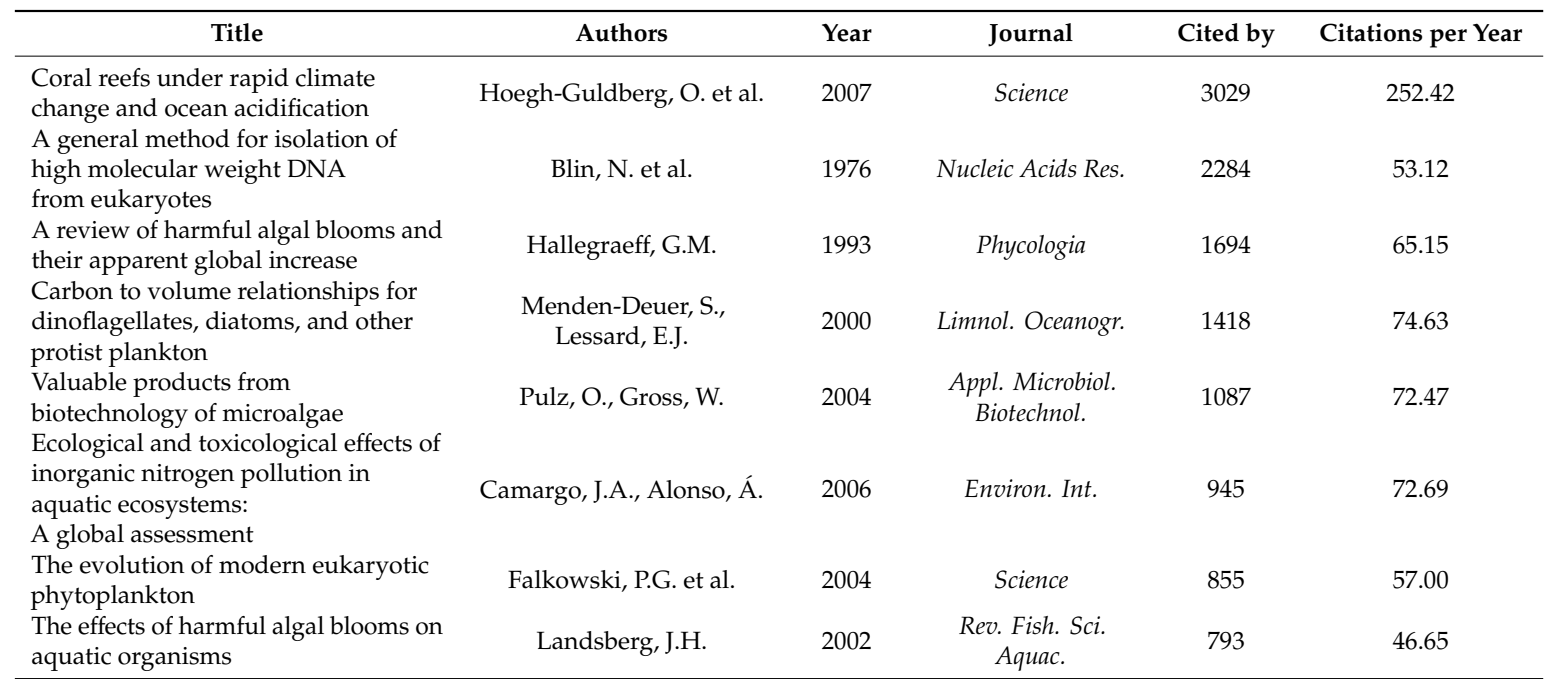


Table 4. Cont.

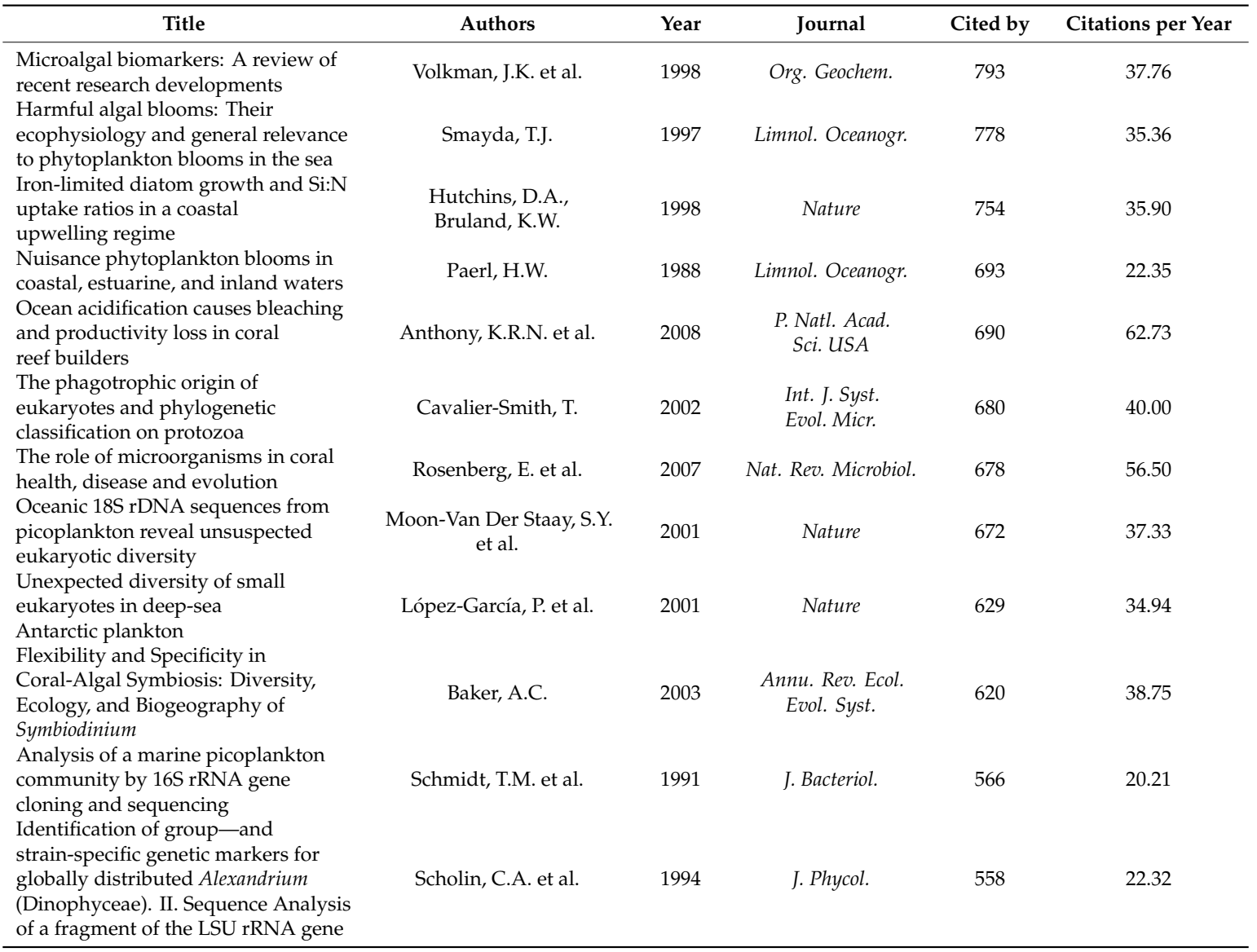

\subsection{Keywords Analysis}

Keyword co-occurrence and their affinity are indicated in Figure 4. In this analysis, 41 keywords were plotted and distributed into five communities. The first community (red color) revolved around the keywords "harmful algal blooms", "red tide" and "toxins", probably influenced by research related to the increase in harmful algal blooms involving the taxa "Alexandrium" and "Karenia brevis". The second community (green color) revolved around the keywords "phytoplankton", "mixotrophy" and "grazing", probably influenced by enforcements to understanding dinoflagellate interactions with others organisms (e.g., bacteria, diatoms and cyanobacteria) and their nutrition strategies. The third community (yellow color) revolved around the keywords, "taxonomy", "ultrastructure" and "phylogeny", probably influenced by evolutionary relationships and taxonomic refinements and corrections within this group. The fourth community (purple color) revolved around paleontological studies that used the keywords "dinoflagellate cysts", "biostratigraphy" and "palynology". Finally, the fifth community (blue color) revolved around the keywords "Symbiodinium", "Coral bleaching" and "photosynthesis", influenced by coral-endosymbiont interactions and the effects of climate change on coral ecosystems. An additional keywords analysis of the last decade data, using author keywords that appeared at least 50 times, was carried out and the results were represented as a cloudword (Figure S2). As in Figure 4, the same keywords could be observed with the emergence of some new keywords: "Marine drugs", "Chemistry" and "Microalga". 


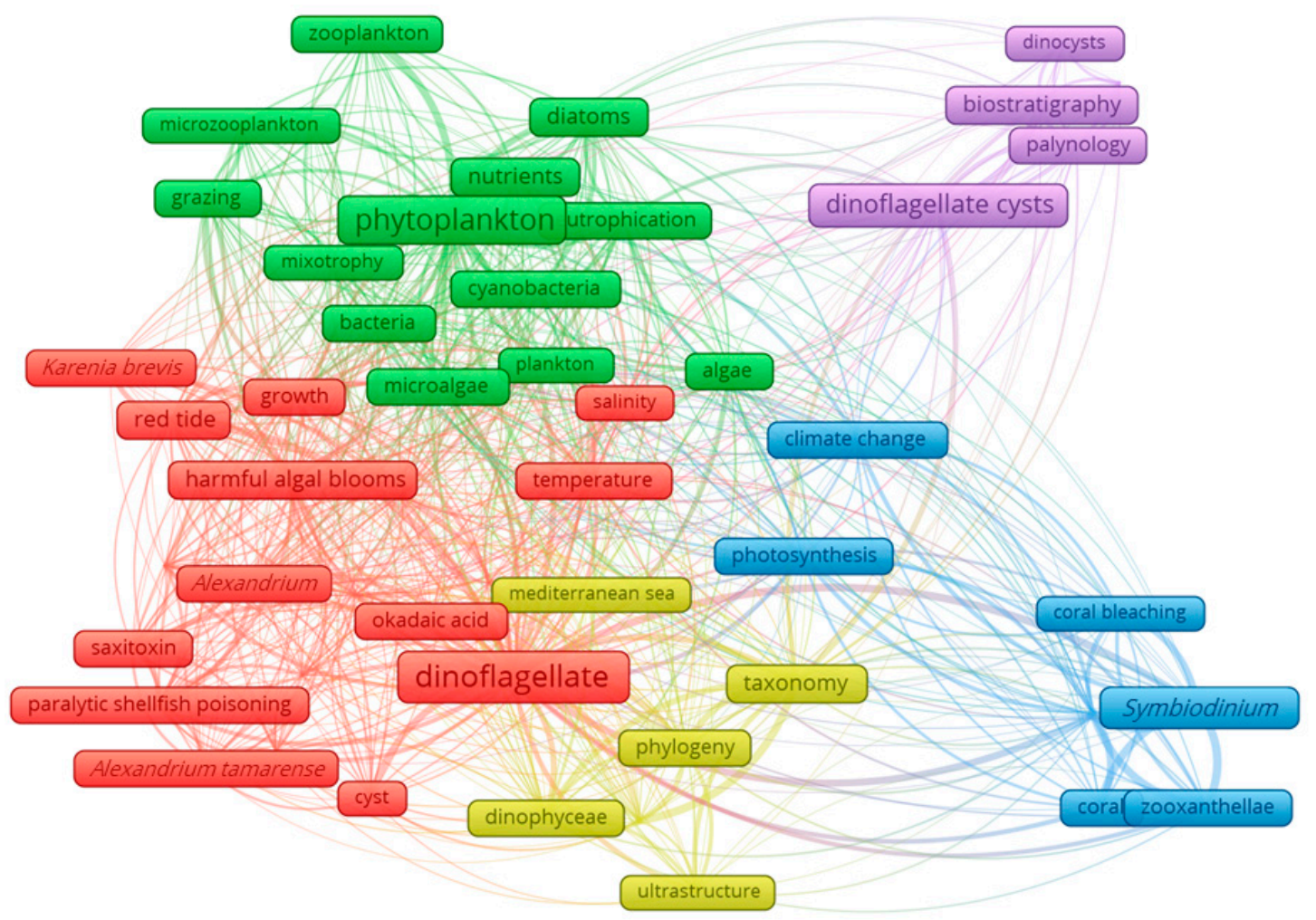

Figure 4. Keywords communities and their associations regarding dinoflagellate research.

Figure 5 shows the top ten genera of dinoflagellates that appeared in the title, abstract or keywords of the published publications. Alexandrium leaded this ranking, followed by Prorocentrum, Symbiodinium and Gymnodinium - these appeared in at least a thousand publications. Ceratium, Protoperidinium and Noctiluca, located at the last positions of this ranking, were associated to almost six times fewer published publications than Alexandrium.

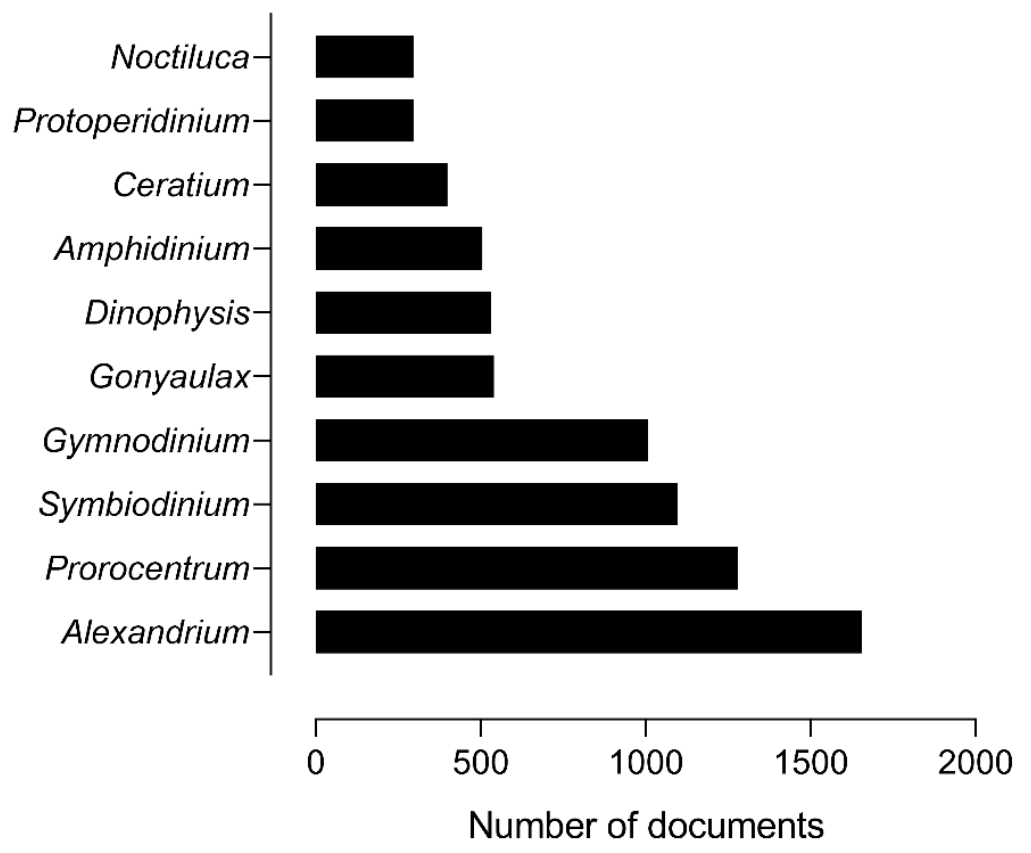

Figure 5. Representation of the number of publications related to specific genera of dinoflagellates. 


\subsection{Modeling Scientific Production}

Economic (GDP), environmental (EPI) and social (HDI) indexes indicated significant influence on the scientific production of dinoflagellate literature. Fish production (both aquaculture and capture) was also the outcome of the model, however, while the capture had a positive relationship with dinoflagellate publications, the aquaculture had a negative effect. The fertilizer consumption did not indicate a significant influence (Figure 6).

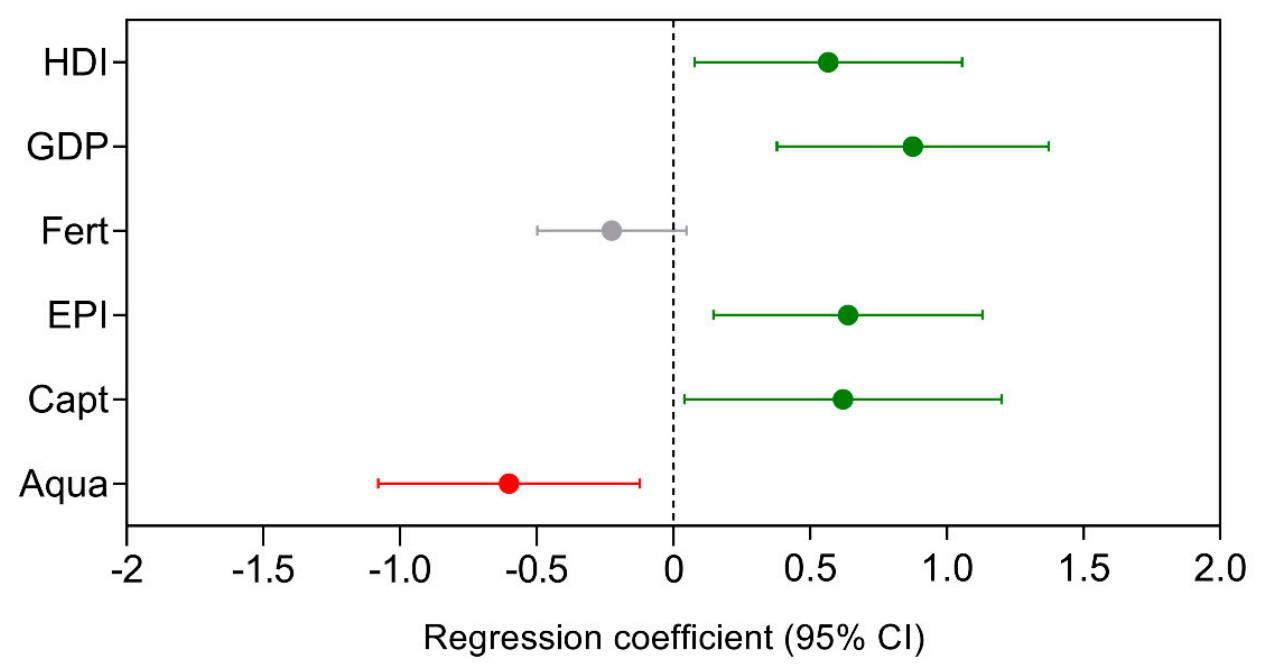

Figure 6. Coefficient estimates ( $\pm 95 \%$ confidence intervals) indicating the magnitude and direction economic, environmental and social variables tested for a model of scientific production of dinoflagellates. Gray markers represent predictors without significant influence, red and green represent negative and positive effects, respectively.

\section{Discussion}

First of all, it is necessary to mention that the number of publications on dinoflagellates is certainly greater than those reported in this study. This is related to many local, regional or national journals that are not indexed in large and international databases (such as Elsevier Scopus). Many publications on dinoflagellates in Latin America, for example, have not been published in indexed journals (e.g., [26-28]). However, recent research efforts have been initiated to showcase Latin American research conducted on harmful algal, including dinoflagellates [29]. Some possible motives of publishing in local journals include: (1) meeting the requirements of funding agencies, (2) easier publishing in the native language and/or (3) contributing to the evolution of local journals [30].

Interestingly, 1000 publications should have been achieved in 2017 according to the exponential regression model, which, however, did not occur (Figure 1). The divergence between the number of publications and the exponential trend hints towards a resource limitation, such as for example human resources and/or financial funding limitation. It is likely that this divergence may have been induced by the financial crisis of 2008 . The implemented interventions by public authorities to alleviate the consequences of the financial crises resulted in multiple financial cuts for scientific research of several countries [31] with a presumably time delayed effect on dinoflagellate research output. In summary, a linear regression model expressed well the growth of the number of research papers on phytoplankton between 1991 and 2013 [32]. Two linear trends were observed within the worldwide microalgae research, the first was from 1970 to 2005 and the second from 2005 to the present [21]. Therefore, although linear models are often used successfully for phytoplankton studies, in the present study an exponential model was more suitable and it allowed illustrating the political and economic evidence that negatively affected dinoflagellate research.

The global scientific production on dinoflagellates can be related to social, economic and environmental aspects. The United States has long been the most productive and influential research 
country in the world, and when analyzing data from 1970 to 2019, the USA still appears as the top country that publishes the most publications in several bibliometric studies [21,33,34]. However, China overtook the United States in 2018 and became the quantitative largest producer of scientific articles in the world. The United States still invests the highest amount of financial resources on research and development (around USD 500 billion), while China stood second (around USD 400 billion) in 2015 with increased funding trends on research and development over the recent years. The spent funding of the United States, on the other hand, remained on the same level in relation to previous years [35]. Although the United States spearheaded the two analyses of publications by country (Figure 2 and Table S1), a substantial increase in the number of publications by China was observed and it rose from the sixth to the second place, when analyzing both the last 50 and 10 years, respectively.

The Elsevier Scopus classifies the CNRS and the Chinese Academy of Sciences as research centers, as well as the Alfred-Wegener-Institut, Woods Hole Oceanographic, University of Tokyo. However, it should be mentioned that CNRS is the French National Centre for Scientific Research and it provides a significant amount of funding for basic research in France. In a similar way, the Chinese Academy of Sciences is an umbrella body of research centers. Therefore, they cannot be directly compared to regional research institutions. Furthermore, although the United States leads the ranking in the number of publications on dinoflagellates, only one American institution appears in the top 20 research centers. This observation may be related to American research being distributed over several research centers with diverse funding resources and not being centralized as for example in case of the French CNRS and the Chinese Academy of Sciences.

Others phytoplankton groups (mainly, diatoms and cyanobacteria) were identified within dinoflagellate research, (Figure 3). This can be explained by the assumed dominant role of diatoms for primary production and the carbon cycle in the oceans. Diatoms have been considered model organisms for oceanic phytoplankton research which has been reevaluated over the past few decades [36-38]. On the other hand, cyanobacteria are the largest group of prokaryotic organisms known for their potential toxicity in marine, freshwater and eutrophic environments and therefore closely related to HAB research $[39,40]$. It is likely that dinoflagellate research on understanding physiological dynamics, bloom causes and consequences, and the biosynthesis of secondary metabolites has been studied together with other HAB species.

Figures 4 and 5 highlight the Symbiodinium genus probably due to two issues: (1) the great effort in the last decade to reorganize the diversity of this genus into a revised hierarchical structure and (2) the close relation to coral reef research. The nine clades recognized in the literature [41] have recently been reorganized into six new genera (in addition to Symbiodinium) belonging to the Symbiodiniaceae family [42]. In addition, the most active countries in the fifth community of keywords (blue color) (Figure 4) are countries in Oceania which may be related to the location of the Great Barrier Reef and of other tropical coral reefs, and the reoccurrence of coral reef bleaching events in these regions [43-45]. The evolutionary success of reef corals over time has been strongly linked to the mutualistic relationship with endosymbiont dinoflagellates. The benefits of this relationship include the supply and exchange of inorganic nutrients (carbon, nitrogen, phosphorus, etc.) that are converted into carbohydrates, amino acids and other secondary metabolites under photoautotrophic pathways. Although dinoflagellates from the Symbiodiniaceae family are almost always associated to a symbiotic lifestyle, they can also be found in free-living mode [46]. The mutualistic relationship can lead to biased conclusions because many publications on coral reefs may occasionally contain in their keywords terms such as "Symbiodinium" or "Zooxanthellae"—as, for example, in the case of the most cited publication reported in our investigation. Figure 4 also shows the palynology as another active subarea in dinoflagellate research. A number of dinoflagellate species produce resting cysts that have the potential (1) to become fossilized in sediments or (2) to be transported via ships' ballast waters $[47,48]$. The transportation of sediments and water containing dinoflagellate cysts has led to a global dispersion of bloom-forming dinoflagellate species. Efforts in this research subarea have been 
related to fossil dinoflagellate cysts which are a useful tool for reconstructing past environmental and oceanographic conditions [48,49].

Figure 5 demonstrates that the number of publications related to nontoxic dinoflagellate genera (Ceratium and Noctiluca) was lower than toxic dinoflagellate genera, which indicates a greater research interest on toxin-producing species. Alexandrium genus, that led the ranking of dinoflagellate genera, is the major harmful dinoflagellate bloom genus with respect to diversity, impact potential and cascading ecosystem consequences [11]. This suggests that interest in studying a certain dinoflagellate genus (or species) increases as new evidence of a toxic potential is reported. Moreover, it should be taken into account that some dinoflagellate species were taxonomically reclassified over time (for example, Karlodinium veneficum and its basionym Gymnodinium veneficum and Ceratium genus that recently was subdivided into Ceratium and Tripos for freshwater and marine species, respectively) [50,51].

Regarding the GLM, positive relationship between fish catch and dinoflagellate publications may be related to HAB issues and their impacts on the fishery industry-which is mainly composed by marine fishing ( $87.5 \%$ of total fish catch) [52-54]. On the other hand, a negative relationship between aquaculture production and dinoflagellate publications was observed maybe due to aquaculture production includes most freshwater (51 million tons) than marine (30.8 million tons) production [55]. Understanding the main related factors leading to harmful dinoflagellates blooms is a crucial step for appropriately managing aquaculture and agriculture activities. The escalation on food production increased the amount of nitrogen compounds released in receiving waters [56,57]. Moreover, regions that reported an increase in the agricultural activities (terrestrial and aquatic) experienced, almost in the same proportion, the increasing frequency and environmental impact of HABs [56]. Although the nitrogen role on dinoflagellate blooms have not been fully elucidated, this algae group have the highest urease activity per cell than any other phytoplankton group [58], and in some cases, the urea uptake can increase the toxicity of dinoflagellate [59]. Thus, understanding the causes and controlling factors of dinoflagellate blooms can contribute to reducing the associated impacts on fishing activity [14].

The Recent trends analysis (Supplementary Materials) indicates the emergence of a new dinoflagellate research subarea: cultivations and biotechnology. This is related to the appearance of new keywords over the past decade, such as "Marine drugs", "Chemistry" and "Microalga"-a common term in publications that refer to cultivation and biotechnology of phytoplankton (Figure S2). These results, when related to the rise of the journal Marine Drugs, may possibly be associated to the interest in cultivating dinoflagellates to produce potential raw material for new drugs formulation with biological activities.

\section{Future Directions}

The results presented in the previous sections give evidence to two emerging future hotspots in dinoflagellate research: (1) taxonomy and classification, (2) harmful dinoflagellate blooms and (3) cultivation and biotechnology. Figure 7 demonstrates a flowchart of the main emerging subareas for dinoflagellate research. Research using "omics" (i.e., genomics, transcriptomics, proteomics and metabolomics) approach is collated on the top of the flowchart and can help in the identification of species, the detection of nutritional strategies, the interaction of symbiotic relationship with bacteria and cnidarias, and the biosynthesis of biomolecules - especially regarding secondary metabolites. These issues can contribute to the knowledge of the metabolic pathways and mechanisms involved during bloom formation. At the bottom of the flowchart, attention was given to the cultivation of dinoflagellates, and it made, according to the procedures, for optimizing the production of biomass from other cultivated microalgae species. 


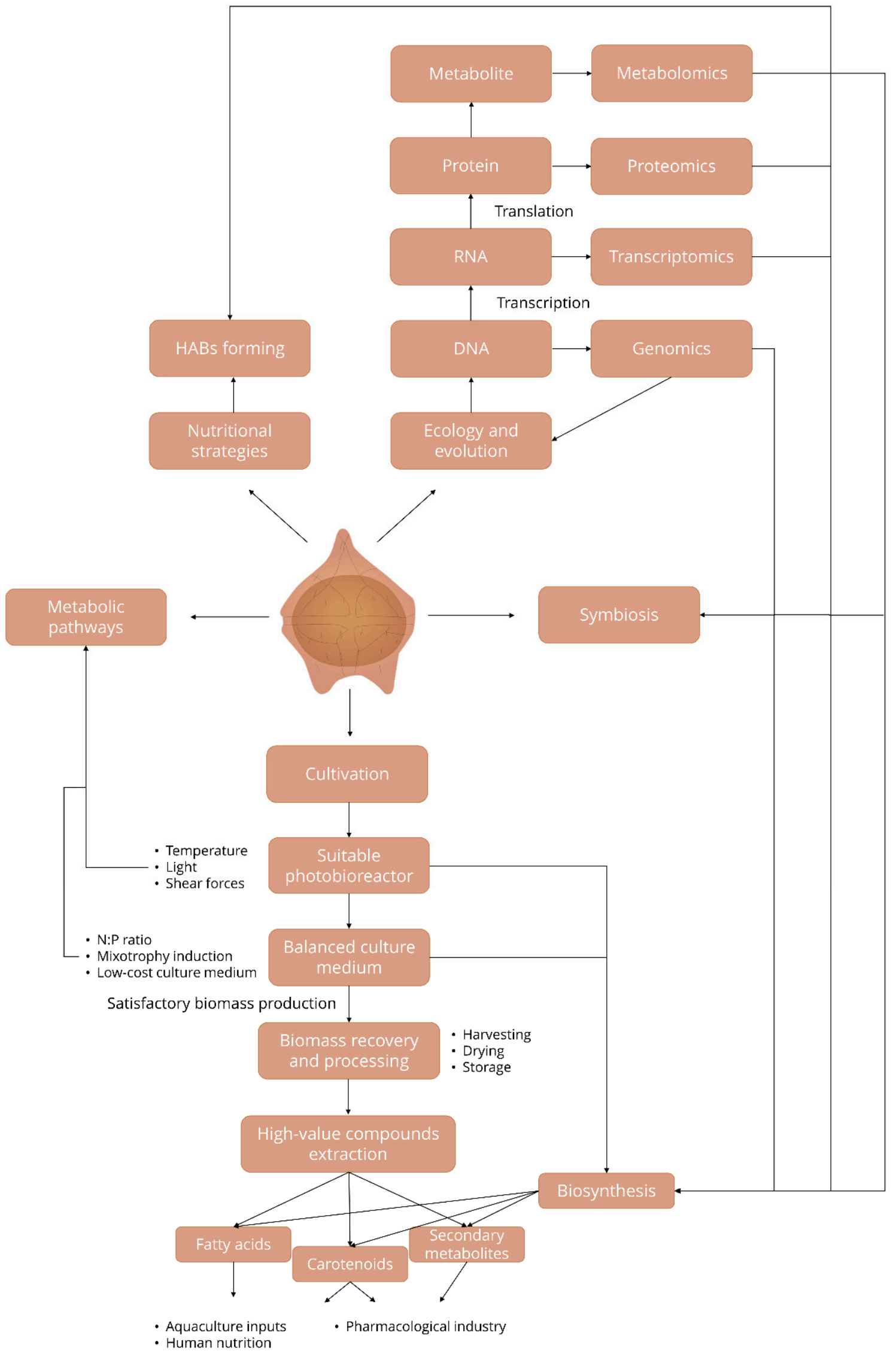

Figure 7. Perspectives for future dinoflagellate research. 
The development and use of robust platforms for data sharing and knowledge transfer/dissemination will certainly contribute and facilitate a fast achievement of new solutions regarding taxonomic and metabolic classifications. Several existing databases (e.g., Dictionary of Natural Products, AntiBase, MassBank and Global Natural Products Social Molecular Networking) can be used to share raw data that can contribute to the research advancement on biomolecules from dinoflagellate biomass [60,61].

The main products obtained from cultivating dinoflagellate biomass include: fatty acids that have sustainable applications for animal and human food, and for biodiesel production [62-64], the peridinin apocarotenoid and toxins that have strong antioxidant properties and helps to prevent the formation of tumors [65-67], and also the amino acids and polysaccharides that can also be used in biorefinery models.

The lack of suitable methods for culturing certain dinoflagellates limits potential in vitro and in vivo tests and the commercialization of new drugs. The main difficulty in cultivating dinoflagellates is the sensitivity to the shear forces [68]. The success in the production of dinoflagellate biomass, as well as an improvement in the biosynthesis of secondary metabolites, will be an important step to be achieved and represents a highly promising industry for the next decades [69].

\section{Conclusions}

This scientometric overview demonstrated a constant increase in the number of publications on dinoflagellates from 1970 to 2019. Most of the top publishing countries were recognized for an important marine fish production economy, with a clear interest in mitigating the impacts of harmful algal blooms on capture production and the associated economy. In addition, the United States and the United Kingdom are highly intertwined within a global research network. The bibliometric analysis of dinoflagellate-related publications indicated that there are more publications in developed regions compared with undeveloped regions. Furthermore, a clear research trend towards toxin producing dinoflagellate genera is evident compared to nontoxin-producing genera.

Although a high number of publications have been reported in this study, it is clear that dinoflagellate research will remain active and growing regarding (1) taxonomy and classification issues, (2) harmful dinoflagellate blooms and (3) cultivation and biotechnological use of dinoflagellate biomass. To address these gaps, international cooperation to make higher quality research can focus in future works based on published data (for example, meta-analysis-based approaches) to clarify taxonomic issues. Moreover, studies on the life-cycle assessment of dinoflagellate production must be considered in future works.

Supplementary Materials: The following are available online at http://www.mdpi.com/2304-6775/8/4/50/s1, Figure S1: Number of publications by years at the last decade in the dinoflagellates research, Figure S2: Cloudword representation of main author keywords ( $\mathrm{min} .250$ times) on dinoflagellate research at the last decade, Table S1: Top 10 countries in number of publications on dinoflagellates research, Table S2: Top 10 journals in the number of publications in the last decade. Most information about these journals can be visualized in Table 3.

Author Contributions: Conceptualization, C.Y.B.O. and C.D.L.O.; methodology, C.Y.B.O. and C.D.L.O.; formal analysis, C.Y.B.O. and M.N.M.; investigation, C.Y.B.O., C.D.L.O., M.N.M., E.P.S., D.M.M.D. and A.O.G.; data curation, C.Y.B.O., C.D.L.O. and E.P.S.; writing-original draft preparation, C.Y.B.O.; writing-review and editing, C.D.L.O., M.N.M., E.P.S., D.M.M.D. and A.O.G.; supervision, M.N.M. and A.O.G. All authors have read and agreed to the published version of the manuscript.

Funding: This research was funded by Coordenação de Aperfeiçoamento de Pessoal de Nível Superior (CAPES)_Finance Code 001 and Conselho Nacional de Desenvolvimento Científico e Tecnológico (CNPq) for the aid granted to A.O.G. (PQ 308063/2019-8).

Conflicts of Interest: The authors declare no conflict of interest.

Availability of Data and Material: The datasets used in this study are available and can be requested from the corresponding author for future research. 


\section{References}

1. Mello, F.D.; Braidy, N.; Marçal, H.; Guillemin, G.; Nabavi, S.M.; Neilan, B.A. Mechanisms and effects posed by neurotoxic products of cyanobacteria/microbial eukaryotes/dinoflagellates in algae blooms: A review. Neurotox. Res. 2018, 33, 153-167. [CrossRef] [PubMed]

2. Saldarriaga, J.F.; Taylor, F.J.R.M. Dinoflagellata. In Handbook of the Protists, 2nd ed.; Springer International Publishing: Berlin/Heidelberg, Germany, 2017; pp. 625-678. ISBN 9783319281490.

3. Taylor, F.J.R.; Hoppenrath, M.; Saldarriaga, J.F. Dinoflagellate diversity and distribution. Biodivers. Conserv. 2008, 17, 407-418. [CrossRef]

4. LaJeunesse, T.C. Diversity and community structure of symbiotic dinoflagellates from Caribbean coral reefs. Mar. Biol. 2002, 141, 387-400. [CrossRef]

5. Lundholm, N.; Moestrup, Ø. The Biogeography of harmful algae. In Ecology of Harmful Algae; Springer: Berlin/Heidelberg, Germany, 2006; pp. 23-35.

6. Wang, D.Z. Neurotoxins from marine dinoflagellates: A brief review. Mar. Drugs 2008, 6, 349-371. [CrossRef]

7. Baden, D.G. Marine food-borne dinoflagellate toxins. Int. Rev. Cytol. 1983, 82, 99-150. [CrossRef]

8. Hallegraeff, G.M. A review of harmful algal blooms and their apparent global increase. Phycologia 1993, 32, 79-99. [CrossRef]

9. Meyer, K.F.; Sommer, H.; Schoenholz, P. Mussel poisoning. J. Prev. Med. 1928, 2, 365-394.

10. Schantz, E.J. Historical perspective on paralytic shellfish poison. In Seafood Toxins; American Chemical Society: Washington, DC, USA, 1984; pp. 99-111.

11. Anderson, D.M.; Alpermann, T.J.; Cembella, A.D.; Collos, Y.; Masseret, E.; Montresor, M. The globally distributed genus Alexandrium: Multifaceted roles in marine ecosystems and impacts on human health. Harmful Algae 2012, 14, 10-35. [CrossRef]

12. Cembella, A.D.; Quilliam, M.A.; Lewis, N.I.; Bauder, A.G.; Dell'Aversano, C.; Thomas, K.; Jellett, J.; Cusack, R.R. The toxigenic marine dinoflagellate Alexandrium tamarense as the probable cause of mortality of caged salmon in Nova Scotia. Harmful Algae 2002, 1, 313-325. [CrossRef]

13. Richlen, M.L.; Morton, S.L.; Jamali, E.A.; Rajan, A.; Anderson, D.M. The catastrophic 2008-2009 red tide in the Arabian gulf region, with observations on the identification and phylogeny of the fish-killing dinoflagellate Cochlodinium polykrikoides. Harmful Algae 2010, 9, 163-172. [CrossRef]

14. Trainer, V.L.; Moore, S.K.; Hallegraeff, G.; Kudela, R.M.; Clement, A.; Mardones, J.I.; Cochlan, W.P. Pelagic harmful algal blooms and climate change: Lessons from nature's experiments with extremes. Harmful Algae 2020, 91, 101591. [CrossRef] [PubMed]

15. Crossetti, L.O.; De Campos Bicudo, D.; Bini, L.M.; Dala-Corte, R.B.; Ferragut, C.; De Mattos Bicudo, C.E. Phytoplankton species interactions and invasion by Ceratium furcoides are influenced by extreme drought and water-hyacinth removal in a shallow tropical reservoir. Hydrobiologia 2019, 831, 71-85. [CrossRef]

16. Meichtry de Zaburlín, N.; Vogler, R.E.; Molina, M.J.; Llano, V.M. Potential distribution of the invasive freshwater dinoflagellate Ceratium furcoides (Levander) Langhans (Dinophyta) in South America. J. Phycol. 2016, 52, 200-208. [CrossRef] [PubMed]

17. Li, X.; Nan, R. A bibliometric analysis of eutrophication literatures: An expanding and shifting focus. Environ. Sci. Pollut. Res. 2017, 24, 17103-17115. [CrossRef]

18. Zhang, Y.; Tao, J.; Wang, J.; Ding, L.; Ding, C.; Li, Y.; Zhou, Q.; Li, D.; Zhang, H. Trends in diatom research since 1991 based on topic modeling. Microorganisms 2019, 7, 213. [CrossRef]

19. Wang, Y.; Hou, S.; Ke, F.; Gao, H. Bibliometric analysis of research on microcystins in China and worldwide from 1991 to 2011. Desalin. Water Treat. 2015, 53, 272-283. [CrossRef]

20. Yu, J.J.; Wang, M.H.; Xu, M.; Ho, Y.S. A bibliometric analysis of research papers published on photosynthesis: 1992-2009. Photosynthetica 2012, 50, 5-14. [CrossRef]

21. Garrido-Cardenas, J.A.; Manzano-Agugliaro, F.; Acien-Fernandez, F.G.; Molina-Grima, E. Microalgae research worldwide. Algal Res. 2018, 35, 50-60. [CrossRef]

22. Noga, P.M.B.; Gomes, D.F. Scientometrical review of dinoflagellate studies in Brazil. Acta Bot. Bras. 2018, 32, 503-510. [CrossRef]

23. Janmaijaya, M.; Shukla, A.K.; Abraham, A.; Muhuri, P.K. A Scientometric study of neurocomputing publications (1992-2018): An aerial overview of intrinsic structure. Publications 2018, 6, 32. [CrossRef] 
24. Montoya, F.G.; Aguilera, M.J.; Manzano-Agugliaro, F. Renewable energy production in Spain: A review. Renew. Sustain. Energy Rev. 2014, 33, 509-531. [CrossRef]

25. Bates, D.; Mächler, M.; Bolker, B.M.; Walker, S.C. Fitting linear mixed-effects models using lme4. J. Stat. Softw. 2015, 67. [CrossRef]

26. Oliveira, A.D.; Filho, J.G.M.; Carvalho, M.; Menezes, T.; Luna, C.; Brenner, W. Novo método de preparação palinológica para aumentar a recuperação de dinoflagelados. Revista Brasileira de Paleontologia 2004, 7, 169-175. [CrossRef]

27. Gárate-Lizárraga, I.; Band-Schmidt, C.J.; Verdugo-Díaz, G.; Muñetón-Gómez, M.D.S.; Félix-Pico, E.F. Dinoflagelados (Dinophyceae) del sistema lagunar Magdalena-Almejas. In Estudios Ecológicos en Bahía Magdalena; D.R. Instituto Politécnico Nacional: Ciudad de México, DF, Mexico, 2007; pp. 145-174.

28. Da SILVA, W.G.; De Souza, P.A. Cistos de dinoflagelados do holoceno da planície costeira de Santa Catarina (Poço PSC-03): Descrições taxonômicas e implicações paleoambientais. Geosciences 2019, 38, 795-812. [CrossRef]

29. Müller, M.N.; Mardones, J.I.; Dorantes-Aranda, J.J. Editorial: Harmful algal blooms (HABs) in Latin America. Front. Mar. Sci. 2020, 7, 34. [CrossRef]

30. Tennant, J.P.; Crane, H.; Crick, T.; Davila, J.; Enkhbayar, A.; Havemann, J.; Kramer, B.; Martin, R.; Masuzzo, P.; Sattler, S.; et al. Ten hot topics around scholarly publishing. Publications 2019, 7, 34. [CrossRef]

31. Moh, F.Y.; Lu, H.P.; Lin, B.H. Contributions to financial crisis research: An assessment of the literature in social science citation index journals from 1990 to 2008. Appl. Econ. 2011, 44, 4689-4700. [CrossRef]

32. Wang, C.; Liu, Y.; Zhan, Q.; Yang, W.; Wu, N. Global trends in phytoplankton research of river ecosystems during 1991-2016: A bibliometric analysis. Fundam. Appl. Limnol. 2018, 191, 25-36. [CrossRef]

33. Aznar-Sánchez, J.A.; Velasco-Muñoz, J.F.; Belmonte-Ureña, L.J.; Manzano-Agugliaro, F. The worldwide research trends on water ecosystem services. Ecol. Indic. 2019, 99, 310-323. [CrossRef]

34. Garrido-Cardenas, J.A.; Esteban-García, B.; Agüera, A.; Sánchez-Pérez, J.A.; Manzano-Agugliaro, F. Wastewater treatment by advanced oxidation process and their worldwide research trends. Int. J. Environ. Res. Public Health 2019, 17, 170. [CrossRef]

35. Tollefson, J. China declared world's largest producer of scientific articles. Nature 2018, 553, 390. [CrossRef] [PubMed]

36. Armbrust, E.V. The life of diatoms in the world's oceans. Nature 2009, 459, 185-192. [CrossRef] [PubMed]

37. Heisler, J.; Glibert, P.M.; Burkholder, J.M.; Anderson, D.M.; Cochlan, W.; Dennison, W.C.; Dortch, Q.; Gobler, C.J.; Heil, C.A.; Humphries, E.; et al. Eutrophication and harmful algal blooms: A scientific consensus. Harmful Algae 2008, 8, 3-13. [CrossRef] [PubMed]

38. Sumper, M.; Brunner, E. Silica biomineralisation in diatoms: The model organism Thalassiosira pseudonana. ChemBioChem 2008, 9, 1187-1194. [CrossRef]

39. Carmichael, W.W. Freshwater blue-green algae (Cyanobacteria) toxins-A review. In The Water Environment; Springer: New York, NY, USA, 1981; pp. 1-13.

40. Flombaum, P.; Gallegos, J.L.; Gordillo, R.A.; Rincón, J.; Zabala, L.L.; Jiao, N.; Karl, D.M.; Li, W.K.W.; Lomas, M.W.; Veneziano, D.; et al. Present and future global distributions of the marine Cyanobacteria Prochlorococcus and Synechococcus. Proc. Natl. Acad. Sci. USA 2013, 110, 9824-9829. [CrossRef] [PubMed]

41. Pochon, X.; Gates, R.D. A new Symbiodinium clade (Dinophyceae) from soritid foraminifera in Hawai'i. Mol. Phylogenet. Evol. 2010, 56, 492-497. [CrossRef]

42. LaJeunesse, T.C.; Parkinson, J.E.; Gabrielson, P.W.; Jeong, H.J.; Reimer, J.D.; Voolstra, C.R.; Santos, S.R. Systematic revision of symbiodiniaceae highlights the antiquity and diversity of coral endosymbionts. Curr. Biol. 2018, 28, 2570-2580. [CrossRef]

43. Le Nohaïc, M.; Ross, C.L.; Cornwall, C.E.; Comeau, S.; Lowe, R.; McCulloch, M.T.; Schoepf, V. Marine heatwave causes unprecedented regional mass bleaching of thermally resistant corals in northwestern Australia. Sci. Rep. 2017, 7, 14999. [CrossRef]

44. Richardson, L.E.; Graham, N.A.J.; Pratchett, M.S.; Eurich, J.G.; Hoey, A.S. Mass coral bleaching causes biotic homogenization of reef fish assemblages. Glob. Chang. Biol. 2018, 24, 3117-3129. [CrossRef]

45. Wooldridge, S. A new conceptual model for the enhanced release of mucus in symbiotic reef corals during 'bleaching' conditions. Mar. Ecol. Prog. Ser. 2009, 396, 145-152. [CrossRef]

46. Manning, M.M.; Gates, R.D. Diversity in populations of free-living Symbiodinium from a Caribbean and Pacific reef. Limnol. Oceanogr. 2008, 53, 1853-1861. [CrossRef] 
47. Hallegraeff, G.M.; Bolch, C.J. Transport of toxic dinoflagellate cysts via ships' ballast water. Mar. Pollut. Bull. 1991, 22, 27-30. [CrossRef]

48. Zonneveld, K.A.F.; Pospelova, V. A determination key for modern dinoflagellate cysts. Palynology 2015, 39, 387-409. [CrossRef]

49. Rachid, J.; Hssaida, T.; Hamoumi, N.; Terhzaz, L.; Spezzaferri, S.; Frank, N.; Daghor, L. Palynological study of carbonated mounds during the holocene along the Atlantic and Mediterranean Moroccan margins. Rev. Palaeobot. Palynol. 2020, 278, 104213. [CrossRef]

50. Daugbjerg, N.; Hansen, G.; Larsen, J.; Moestrup, O. Phylogeny of some of the major genera of dinoflagellates based on ultrastructure and partial LSU rDNA sequence data, including the erection of three new genera of unarmoured dinoflagellates. Phycologia 2000, 39, 302-317. [CrossRef]

51. Gómez, F. Reinstatement of the dinoflagellate genus Tripos to replace Neoceratium, marine species of Ceratium (Dinophyceae, Alveolata). Cicimar Oceánides 2013, 28, 1-22.

52. Ajani, P.; Harwood, D.T.; Murray, A. Recent trends in marine phycotoxins from Australian coastal waters. Mar. Drugs 2017, 15, 33. [CrossRef]

53. Hallegraeff, G.M.; Albinsson, M.E.; Dowdney, J.; Holmes, A.; Mansour, M.P.; Seger, A. Prey preference, environmental tolerances and ichthyotoxicity by the red-tide dinoflagellate Noctiluca scintillans cultured from Tasmanian waters. J. Plankton Res. 2006, 28, 725-736. [CrossRef]

54. Seger, A.; Dorantes-Aranda, J.; Müller, M.; Body, A.; Peristyy, A.; Place, A.; Park, T.; Hallegraeff, G. Mitigating fish-killing Prymnesium parvum algal blooms in aquaculture ponds with Clay: The importance of pH and clay type. J. Mar. Sci. Eng. 2015, 3, 154-174. [CrossRef]

55. Food and Agriculture Organization of the United Nations. The State of World Fisheries and Aquaculture 2018-Meeting the Sustainable Development Goals; Food and Agriculture Organization of the United Nations: Rome, Italy, 2018.

56. Glibert, P.M.; Harrison, J.; Heil, C.; Seitzinger, S. Escalating worldwide use of urea-a global change contributing to coastal eutrophication. Biogeochemistry 2006, 77, 441-463. [CrossRef]

57. Jiang, Z.; Chen, Q.; Zeng, J.; Liao, Y.; Shou, L.; Liu, J. Phytoplankton community distribution in relation to environmental parameters in three aquaculture systems in a Chinese subtropical eutrophic bay. Mar. Ecol. Prog. Ser. 2012, 446, 73-89. [CrossRef]

58. Glibert, P.M.; Azanza, R.; Burford, M.; Furuya, K.; Abal, E.; Al-Azri, A.; Al-Yamani, F.; Andersen, P.; Anderson, D.M.; Beardall, J.; et al. Ocean urea fertilization for carbon credits poses high ecological risks. Mar. Pollut. Bull. 2008, 56, 1049-1056. [CrossRef] [PubMed]

59. Leong, S.C.Y.; Murata, A.; Nagashima, Y.; Taguchi, S. Variability in toxicity of the dinoflagellate Alexandrium tamarense in response to different nitrogen sources and concentrations. Toxicon 2004, 43, 407-415. [CrossRef] [PubMed]

60. Horai, H.; Arita, M.; Kanaya, S.; Nihei, Y.; Ikeda, T.; Suwa, K.; Ojima, Y.; Tanaka, K.; Tanaka, S.; Aoshima, K.; et al. MassBank: A public repository for sharing mass spectral data for life sciences. J. Mass Spectrom. 2010, 45, 703-714. [CrossRef] [PubMed]

61. Wang, M.; Carver, J.J.; Phelan, V.V.; Sanchez, L.M.; Garg, N.; Peng, Y.; Nguyen, D.D.; Watrous, J.; Kapono, C.A.; Luzzatto-Knaan, T.; et al. Sharing and community curation of mass spectrometry data with global natural products social molecular networking. Nat. Biotechnol. 2016, 34, 828-837. [CrossRef]

62. Molina-Miras, A.; López-Rosales, L.; Sánchez-Mirón, A.; Cerón-García, M.C.; Seoane-Parra, S.; García-Camacho, F.; Molina-Grima, E. Long-term culture of the marine dinoflagellate microalga Amphidinium carterae in an indoor LED-lighted raceway photobioreactor: Production of carotenoids and fatty acids. Bioresour. Technol. 2018, 265, 257-267. [CrossRef]

63. Oliveira, C.Y.B.; D'Alessandro, E.B.; Antoniosi Filho, N.R.; Lopes, R.G.; Derner, R.B. Synergistic effect of growth conditions and organic carbon sources for improving biomass production and biodiesel quality by the microalga Choricystis minor var. minor. Sci. Total Environ. 2020, 143476. [CrossRef]

64. Kumar, B.R.; Deviram, G.; Mathimani, T.; Duc, P.A.; Pugazhendhi, A. Microalgae as rich source of polyunsaturated fatty acids. Biocatal. Agric. Biotechnol. 2019, 17, 583-588. [CrossRef]

65. Galasso, C.; Nuzzo, G.; Brunet, C.; Ianora, A.; Sardo, A.; Fontana, A.; Sansone, C. The marine dinoflagellate Alexandrium minutum activates a mitophagic pathway in human lung cancer cells. Mar. Drugs 2018, 16, 502. [CrossRef] 
66. Barros, M.P.; Pinto, E.; Colepicolo, P.; Pedersén, M. Astaxanthin and peridinin inhibit oxidative damage in $\mathrm{Fe}^{2+}$-loaded liposomes: Scavenging oxyradicals or changing membrane permeability? Biochem. Biophys. Res. Commun. 2001, 288, 225-232. [CrossRef]

67. Chuyen, H.V.; Eun, J.B. Marine carotenoids: Bioactivities and potential benefits to human health. Crit. Rev. Food Sci. Nutr. 2017, 57, 2600-2610. [CrossRef] [PubMed]

68. López-Rosales, L.; García-Camacho, F.; Sánchez-Mirón, A.; Contreras-Gómez, A.; Molina-Grima, E. An optimisation approach for culturing shear-sensitive dinoflagellate microalgae in bench-scale bubble column photobioreactors. Bioresour. Technol. 2015, 197, 375-382. [CrossRef] [PubMed]

69. Camacho, F.G.; Rodríguez, J.J.G.; Mirón, A.S.; Belarbi, E.H.; Chisti, Y.; Grima, E.M. Photobioreactor scale-up for a shear-sensitive dinoflagellate microalga. Process. Biochem. 2011, 46, 936-944. [CrossRef]

Publisher's Note: MDPI stays neutral with regard to jurisdictional claims in published maps and institutional affiliations.

(C) 2020 by the authors. Licensee MDPI, Basel, Switzerland. This article is an open access article distributed under the terms and conditions of the Creative Commons Attribution (CC BY) license (http://creativecommons.org/licenses/by/4.0/). 